\title{
A DONA DO POEMA
}

Fabio Martins Moreira ${ }^{1}$

Ontem acordei no meio da noite. A inspiração havia chegado. Finalmente, já era hora, tardou, mas se fez presente. Do nada ela surgiu. De onde ela vem eu não sei. Escondida em algum canto da alma ela decidiu se revelar.

A máxima veio à tona: nós não escolhemos o poema, ele é que controla o processo. Tudo bem, aceito a sina, não nego a batalha e me sujeito a seus caprichos. O que importa são as palavras que surgiram. E surgiram com força, imensas e tumultuadas, exigindo seu espaço. Elas queriam vida, dotadas de desejo, com tamanha ânsia que superou a angústia com que eu as buscava.

A inspiração havia alcançado as palavras onde os desejos se encontram. O desejo do poeta e o capricho das palavras, susceptíveis e lascivos no momento da criação. E o texto ganha vida. Frases e períodos soltos vão se acumulando e a sintaxe costura tudo em uma forma ainda indefinida.

Estou contente. O que mais um poeta poderia querer? Mas tenho medo. Sim, muito medo. Não que eu esteja desprezando a dádiva. Deveria mais é aproveitar o momento. Desejos e palavras. Em meio a isso, o receio de a que a inspiração se perca novamente me deixa intrigado, preocupado, inseguro.

Muitas lembranças se fazem cúmplices da criação, com detalhes sugestivos que contribuem para o surgimento da arte. Outras, doídas e inconvenientes desviam a atenção do objetivo, levam o pensamento para longe e com grande esforço a mente retorna ao texto e à inspiração.

Pensando bem, parece que tudo conspira contra a inspiração e o texto. Quando o texto começa a engrenar, vem a lembrança de algo que desvia a atenção. No momento que tudo se organiza novamente, surge o sono que deixa o texto distante outra vez. Eu me esforço. Luto e

\footnotetext{
1 Mestrando em Letras pela Universidade Regional Integrada do Alto Uruguai e das Missões, URI, Campus de Frederico Westphalen - RS. fabiopoeta@yahoo.com.br
} 
permaneço com o texto em foco, desviar os percalços é a meta, a necessidade, é simplesmente vital.

Se a vida fosse apenas texto e inspiração, tudo seria mais simples. Mas a vida existe fora do poema e também tem suas preocupações. Amanhã seria um dia cheio, quantas coisas a fazer. Quantas preocupações. Vai faltar tempo, vai faltar dinheiro, vão faltar palavras. Palavras? Meu Deus o texto está se perdendo outra vez. Calma, concentração. Voltei ao caminho do poema.

Consegui produzir mais algumas frases. O texto está indo bem novamente. Agora sim! Nada de lembranças inconvenientes. Mais uma frase. Afastei as preocupações que estão por vir. Tudo no lugar. Texto e inspiração juntos. Na verdade estava indo bem. O telefone toca. Por quê? Sim por que tem que tocar agora? Certamente Álvares de Azevedo e Byron não tiveram que passar por isso. Toca novamente. Ai ai ai. Vai que seja importante. Pronto? Não obrigado não quero nenhum cartão! Eu sou muito educado, não queria ser indelicado de forma alguma. Escuta amiguinha, que parte do não você não entendeu? Eu acho que peguei pesado. Antes que eu pudesse pedir desculpas: a nossa empresa tem o melhor seguro de vida para oferecer ao senhor... Seguro? Não, não é o que me faltava. E você amiguinha do banco você tem seguro de vida? Se não tiver seria bom faz̧er! Finalmente a vendedora desligou. Onde eu estava mesmo?

Sim, de volta ao texto. Nada de lembranças doídas, nada de sono, nada de preocupações, nada de telefonemas importunos. Pronto para escrever... Infelizmente nada de inspiração. Aonde foi? Assim como surgiu, a inspiração foi embora. Meu medo não era infundado. Ela me abandonou. Tento buscá-la ao meu redor, dentro de mim e nada. Eu sempre me perguntei em que lugar distante ela se escondia.

Não tem jeito. Como eu disse no início, o poema é que controla o processo e a inspiração é a sua dona. O que me resta: aceitar a sina. O texto fica pela metade.

Vou dormir. O corpo cansado pede por alívio. Mas cadê o sono? Havia fugido também, deixou a insônia no lugar. Recorro às lembranças, mas a mente estava cansada demais para pensar e até mesmo as preocupações ficam sem resposta.

O que me resta? Esperar a inspiração voltar. Estático, com olhar voltado para o nada. Em momentos de vazio e solidão nem mesmo o telefone resolve tocar. 